\title{
Suba László: Az árumozgás-felügyelet elektronizálási folyamata a vámhatóságnál
}

\begin{abstract}
Absztrakt
A vámhatóságok munkájának egyik jelentös eleme a vámfelügyelet álló és mozgásban lévö áruk folyamatos figyelemmel kísérése. Ezen szállitások kiemelt kockázatot jelentenek. Az Európai Unió az elmúlt évtizedben sikeresen vezetett be olyan informatikai rendszereket, amelyek segitségével ez a feladat hatékonyan ellátható, a szállitások ellenörzés alatt tarthatók. A rendszerek ma már a napi vámhatósági munka nélkülözhetetlen eszközei. A szerzö - a modernizálás jogtörténeti hátterének bemutatását követöen - ennek a fejlesztésnek a jelentősebb állomásait kívánja bemutatni, és igyekszik azokból általános érvényü következtetéseket levonni.
\end{abstract}

\section{Abstract}

One important element of the work of customs authorities is the continuous monitoring of goods under customs supervision and moving goods. These deliveries pose a high risk. Over the past decade, the European Union has successfully introduced IT systems that can help to carry out this task efficiently, delivering control over deliveries. Systems are nowadays an indispensable tool of daily customs work. After presenting the legal history background of modernization, the author intends to present the major stages of this development and seek to draw general conclusions from them.

$* * *$

\section{Egy kis vámjogtörténet - avagy mit akarunk elektronizálni?}

\subsection{Az utalási eljárás}

Ha a mai modern vámjogi szabályozást és annak előzményeit kívánjuk vizsgálni, akkor elöször a vámjog szabályozásáról szóló 1924. évi XIX. törvénycikk rendelkezéseit kell szemügyre vennünk. Annál is inkább igaz ez, mert az említett jogszabály javaslatához 1924. május 28-án dr. báró Korányi Frigyes pénzügyminiszter által benyújtott megokolás (mai szóhasználattal élve: miniszteri indokolás) szerint „Magyarországnak olyan kodifikációja, amely a fennebb emlitett joganyagot kimeritöen, rendszeresen, a modern árúforgalom és a modern tudományos fejlödés igényeinek megfelelöen rendezte volna, eddig nem volt". ${ }^{501}$ Az említett - majdnem egy évszázad távlatából is rendkívül korszerünek mondható - jogszabály II. fejezete tartalmazza a vámeljárás fajait, azaz tulajdonképpen a vámeljárásokat. Ezek egyikeként sorolja fel az ún. utalási eljárást, amely a mai árutovábbításnak felel meg. Az utalási eljárásról a törvénycikk 64. §-a ezt mondja: „Vámárúkat további vámeljárás végett valamely vámhivataltól (az utaló hivataltól) más vámhivatalhoz (az elintézö hivatalhoz) csak vámhivatali felügyelet mellett lehet továbbitani. Erre a célra szolgál az utalási eljárás. Az utalt árúk azonosságát biztositani kell (38. §). Az átviteli árúk utalási eljárás

${ }^{501}$ Az 1924. évi XIX. tc. indokolása, p. 1. 
alá esnek. [...] Az utalás az ügyfél inditványára vagy a bemondójegye, vagy a kiséröjegyes eljárással történik; az ügyfél inditványa nélkül, hivatalból csak lefoglalt árúk szállitásánál lehet alkalmazni az utalási eljárást. Az utalási eljárásban az ügyfélre az a kötelezettség hárul, hogy az árút azonosságának megóvása mellett változatlan állapotban az elöírt határidőn belül az elintézö hivatal elé kell állítania. "502 Az utalás bemondójegyes vagy kíséröjegyes eljárás formájában volt lebonyolítható. A két forma között az volt a különbség, hogy a bemondójegyes eljárás a vasúttársaságok és más nyilvános szállítóintézetek által igénybevehető, külön árubevallás és biztosíték nélkül alkalmazható eljárás volt; a kísérőjegyes eljárás volt az alapforma, amely esetében árubevallást kellett tenni és biztosítékot kellett szolgáltatni. Mindkét eset közös eleme volt, hogy az elintéző hivatal a vám elé állítást az utaló hivatal részére visszaigazolta. ${ }^{503}$

\subsection{Az árutovábbítás}

A tervgazdálkodás idején jelentősen visszaszorult a vámok szerepe, ezért új normára volt szükség. Megszületett tehát a vámjog szabályozásáról szóló 1951. évi 24. tvr., ami tulajdonképpen a korábbi vámtörvény kivonata volt, és hamar alkalmatlannak bizonyult. Az ezt rövidesen felváltó „,1954. évi 16. tvr. hasonlított a korábbi tvr.-hez annyiban, amennyiben a politikai hatalom gyakorlóinak kivánsága szerint a végletekig leegyszerüsitette és elvulgarizálta a vámszabályokat". ${ }^{504}$ A hatvanas évek második felében útjára indított új gazdasági mechanizmus egyik első lépése volt a vámjogi alapszabályokat tartalmazó 1966. évi 2. tvr., illetve a végrehajtására kiadott 9/1966. (II. 5.) Korm. rendelet megalkotása. Jól mutatja a vámok akkortájt még mindig szerény jelentőségét, hogy a részletes szabályokat csak egy évtizeddel később állapították meg, a 39/1976. (XI. 10.) PM-KkM együttes rendeletben. E jogszabály így határozta meg a most már árutovábbítás néven említett vámeljárást: „Árutovábbítás esetén a vámhivatal a vámárut további vámkezelés céljából másik vámhi-vatalhoz utalja. Az. árutovábbitás vámvizsgálatból, a vámáru azonositásából és a vám biztositásából áll." ${ }^{505}$ Mint látható, a jogszabály megszövegezői ekkor még nem hagyták el a meghatározásból az 1924-ben bevezetett „utalás” szót.

Közeledve az európai uniós csatlakozáshoz, 1996. április 1-jén lépett hatályba a vámjogról, a vámeljárásról, valamint a vámigazgatásról szóló 1995. évi C. törvény, amely már jelentős részben tartalmazta az Európai Unióban is ismert jogintézményeket, de azok majdnem teljes körü átvételéhez szükség volt a „második vámtörvény”-ként is ismert 2000-es módosításra. , Vámárunak egyik vámhivatal vámfelügyelete alól bármely másik vámhivatal vámfelügyelete alá helyezése a vámáru továbbitásával történik" - így határozza meg a vámeljárást a törvény 56. §-ának (1) bekezdése. A részletekről pedig ekként rendelkezik: „,(2) Az árutovábbitás vámvizsgálatból, a vámáru azonositásából és a vámteher, áruk esetében pedig - ha e törvény így rendelkezik - a forgalmi adók biztositásából áll. (3) Az árutovábbitás az erre irányuló kérelem elfogadásakor kezdödik, a vámárunak és a vámkezelés szabályai szerint csatolt iratoknak a rendeltetési vagy a kiléptetést végzö vámhivatalnál történt bemutatásakor fejezödik be. ${ }^{, 506}$

\footnotetext{
502 1924. évi XIX. tc. $64 . \S$

503 1924. évi XIX. tc. 66-73. §

${ }^{504}$ ARNOLD Mihály: Ma már holnap van. A magyar gazdaság és a Vám-és Pénzügyőrség. VIVA Média Holding, Budapest, 2002. p. 38.

50539/1976. (XI. 10.) PM-KkM együttes rendelet 34. § (1) bekezdés

506 1995. évi C. törvény 56. §
} 
Immár az Európai Unió tagjaként napjainkban Magyarország is az uniós vámjogot alkalmazza. Hasonlóan a hazánkban a 2004. május elsejei EU-csatlakozáskor hatályba lépett, a Közösségi Vámkódex létrehozásáról szóló, 1992. október 12-i 2913/92/EGK tanácsi rendelet szabályaihoz, ${ }^{507}$ a jelenleg hatályos vámkódex, az Uniós Vámkódex létrehozásáról szóló 2013. október 9-i 952/2013/EUeurópai parlamenti és tanácsi rendelet külön szól a külső és a belső árutovábbítás szabályairól. Ezek szerint „a külsö árutovábbitási eljárás lehetővé teszi a nem uniós áruknak az Unió vámterületén belül egy adott pontról egy másikra történö szállitását, anélkül, hogy a következök bármelyike vonatkozna rájuk: a) behozatali vám; b) egyéb terhek az egyéb vonatkozó hatályban lévö rendelkezések szerint; c) kereskedelempolitikai intézkedések, amennyiben azok nem tiltják az áruknak az Unió vámterületére való belépését, illetve onnan való kilépését”. ${ }^{508}$ A belső árutovábbítási eljárás pedig , lehetővé teszi az Unió vámterületének egyik pontjáról a másikra uniós áruk e vámterületen kivüli területen vagy országon keresztül történö szállitását vámjogi státusukban történö változás nélkül",509

\subsection{Az árutovábbítás elemei}

További vizsgálódásunkhoz szükség van arra, hogy - felhasználva a korábban hatályban volt jogszabályok szövegét is - összefoglaljuk azokat a lényeges elemeket, mozzanatokat, amelyek az árutovábbítást jellemzik. ${ }^{510}$ Ezek a következők:

- Nem uniós árukat, vagy ritkábban uniós árukat, de mindenképpen költségvetési szempontból függő helyzetben lévő árukat

- további vámeljárás végett

- valamely vámhivataltól (az indító hivataltól)

- más vámhivatalhoz (a rendeltetési hivatalhoz)

- csak vámhivatali felügyelet mellett lehet továbbítani. Az áruk nyilvántartásba vételén túl ez úgy valósul meg, hogy az indító hivatalnál

- vámbiztosíték nyújtandó, továbbá

- az áruk azonosságát biztosítani kell.

- Az árutovábbítás az ügyfél indítványára (vámáru-nyilatkozat) indul. Az árutovábbítási eljárásban az ügyfélre az a kötelezettség hárul, hogy

- az árut azonosságának megóvása mellett változatlan állapotban

- az elöírt határidőn belül a rendeltetési hivatal elé kell állítania.

\footnotetext{
507 91. cikk (1) A külső árutovábbítási eljárás lehetővé teszi az alábbiakban meghatározott áru elszállítását a Közösség vámterületén belül egy adott pontról egy másikra: a) nem közösségi áru anélkül, hogy arra behozatali vámok és más terhek, vagy kereskedelempolitikai intézkedések vonatkoznának; b) közösségi áru, a bizottsági eljárásnak megfelelően meghatározott esetekben és feltételek mellett, annak érdekében, hogy a kiviteli intézkedésekben részesülő vagy azok hatálya alá tartozó termékek ne kerüljék meg ezen intézkedéseket vagy ne részesüljenek jogosulatlanul ezen intézkedésekből. - 163. cikk (1) A belső árutovábbítási eljárás, a (2)-(4) bekezdésben megállapított feltételek mellett lehetővé teszi a Közösség vámterületén lévő egyik pontról a másikra közösségi áruk harmadik ország területén keresztül történő szállítását vámjogi helyzetükben történő változás nélkül. Ez a rendelkezés nem érinti a 91. cikk (1) bekezdése b) pontjának alkalmazását.

508 952/2013/EU rendelet 226. cikk (1) bekezdés

509 952/2013/EU rendelet 227. cikk (1) bekezdés

${ }^{510}$ Ehhez az elméleti fejtegetéshez gyakorlati és célszerüségi megfontolásból a hatályos jogi szabályozás terminológiáját használom.
} 


\section{Az árutovábbítás számítógépesítése az Európai Unióban}

\subsection{Az elektronikus közigazgatás térnyerése}

A vámhatósági munka egyik lényeges eleme, hogy bizonyos, szállítás alatt lévő áruk útját, pontosabban megérkezését a rendeltetési helyre követni tudjuk. Mai felgyorsult világunkban ezt a tevékenységet a vámhatóságok hatékonyan csak a szállítmányokkal kapcsolatos adatok elektronikus úton történő cseréje révén tudják ellátni. A vámigazgatási eljárás elektronizálása hazánkban (legalábbis törvényhozási szinten) 1996-ban kezdődött. Az akkor hatályos vámtörvény adott lehetőséget először az árunyilatkozat elektronikus úton való benyújtására. ${ }^{511} 2000$. július 1 -jén lépett hatályba a többi között az a ma is alkalmazandó eljárás, ami egyszerüsitett vámeljárás néven ismert, és ezzel szoros összefüggésben került a jogszabályba az elektronikus vám elé állítás. ${ }^{512}$

Igazán nagy lendületet azonban Magyarország EU-hoz történő csatlakozása kapcsán kapott a számítógépesítés. Az Európai Tanács 2000. márciusi lisszaboni ülésén elfogadta az ún. lisszaboni stratégiát,melynek részeként meghirdették az „e-Európa” elnevezésü, „Információs társadalom mindenkinek” jelszavú programot. „, $A z$ »eEurópa«-program központi felismerése és meghirdetésének fö mozgatórugója az volt, hogy miközben Európa piaci szereplöi immár sikeresen kiaknázzák az információs társadalom és gazdaság elönyeit, addig a közszektor nem. "513 Ennek orvoslására jelölte ki a program számos más feladat végrehajtásán túl az e-közigazgatás kialakítását. A program végrehajtására később e-Európa akciótervek is születtek $(2000,2002,2005)$. A lisszaboni stratégia nyomán az Európai Unió a vámigazgatás területén is fokozatosan teljes körüvé teszi az elektronikus eljárásokat.

Időközben az Európai Unió vámjogi szabályai fölött is eljárt az idő, hiszen, mint a jelenleg hatályos uniós vámkódex preambuluma fogalmaz, az „,1992. október 12-i 2913/92/EGK tanácsi rendelet az 1980-as években a tagállamokban külön-külön alkalmazott vámeljárások integrációján alapult. Ezt a rendeletet bevezetése óta ismételten és jelentös mértékben módositották bizonyos problémák, mint a jóhiszemüség védelme vagy a biztonsági követelmények figyelembevétele, megoldása érdekében." 514 A preambulum több bekezdése - így a 15., a 17-20. és a 43. bekezdés - kitér arra, hogy az informatikai technológia alkalmazása kulcsfontosságú mind a kereskedelem megkönnyítése, mind pedig a vámellenörzések hatékonysága szempontjából.

E célkitüzések végrehajtását szolgálja a Bizottság (EU) 2016/578 végrehajtási határozata (2016. április 11.) az Uniós Vámkódexben előírt elektronikus rendszerek kifejlesztésére és telepítésére vonatkozó munkaprogram létrehozásáról, amely hatályon kívül helyezte az Uniós Vámkódex munkaprogramjának létrehozásáról szóló

\footnotetext{
511 1995. évi C. tv. 52. § (2) bek.: „[...] Kereskedelmi forgalomban a vámszervezet központi szerve engedélyezheti az árunyilatkozat elektronikus úton való benyújtását."

${ }^{512} \mathrm{Az}$ egyszerüsített vámeljárás során az ügyfél a) hiányos adattartalmú árunyilatkozatot ad, vagy b) kereskedelmi okmánnyal (pl. számlával) helyettesíti az árunyilatkozatot, vagy c) az árunak a saját telephelyén való nyilvántartásba vételével ad árunyilatkozatot (mindez együtt: egyszerüsített árunyilatkozat). Itt jön szóba az elektronikus vám elé állítás (tehát az egyszerűsített árunyilatkozat elektronikus úton való benyújtása). Megjegyzendő még, hogy az egyszerüsített árunyilatkozatokhoz bizonyos időszakra vonatkozóan összefoglaló, ún. kiegészítő árunyilatkozatot kell(ett) adni.

${ }^{513}$ FAZEKAS Mariann - FICZERE Lajos: Magyar közigazgatási jog. Általános rész. 6., átd. kiad. Bp., Osiris, 2005., p. 599.

${ }^{514}$ Az Európai Parlament és a Tanács 952/2013/EU rendelete (2013. október 9.) az Uniós Vámkódex létrehozásáról. Preambulum, 12. bekezdés
} 
2014/255/EU végrehajtási határozatot. A 2016-os munkaprogram a következő „telepítési dátumokat" határozza meg a transzeurópai és nemzeti rendszerekre vonatkozóan:

- az elektronikus rendszerek telepítésére nyitva álló időtartam kezdő dátuma, amely alatt az elektronikus rendszer müködése megkezdésének legkorábbi dátumát kell érteni;

- az elektronikus rendszerek telepítésére rendelkezésre álló időszak záró dátuma, amely alatt a következőket kell érteni: a) az az utolsó nap, ameddig valamennyi tagállamnak meg kell kezdenie a rendszerek müködtetését és azokat valamennyi gazdálkodónak használnia kell, valamint b) az átmeneti időszak záró dátuma. ${ }^{515}$

\subsection{Az új számítógépesített árutovábbítási rendszer $\left(N C T S^{516}\right)$ bevezetése}

Az új számítógépesített árutovábbítási rendszer müködéséről és előnyeiről úgy kaphatunk képet a legegyszerübben, ha - célszerüen egy példán keresztül - áttekintjük az árutovábbítás vámeljárásnak a rendszer bevezetését megelőző gyakorlatát. Abban az esetben, ha például egy fuvarozó a régi tranzit rendszerben (Old Transit System OTS) Záhonyból Kölnbe kívánt elszállítani egy kamion árut, az árutovábbítási eljárás megindításához be kellett nyújtani az indító vámhivatalban egy papír alapú vámárunyilatkozatot, és valamilyen módon vámbiztosítékot kell nyújtania azért, hogy ha útközben eltünne a szállítmány, a vámhatóság érvényesíteni tudja az esedékes vámot és nemzeti adókat. A vámhivatal nyilvántartásba vette a szállítmányt, amit az árunyilatkozat két példánya kísért a rendeltetési vámhivatalig, azaz Kölnig. A kölni vámhivatal szintén bejegyezte saját nyilvántartásába a szállítmányt, és $\mathbf{a z}$ árunyilatkozat egy példányát egy-két héten belül visszaküldte Záhonyba, jelezve ezzel, hogy az árutovábbítási vámeljárás rendben befejeződött, és az indító vámhivatalnál nyújtott vámgarancia felszabadítható.

Gyakorta előfordult, hogy a szállítmány útközben eltünt - ellopták, a fuvarozó vagy a címzett nem mutatta be a rendeltetési vámhivatalnál -, és ebben az esetben hosszas keresési eljárást kezdeményezett az indító vámhivatal annak megállapítására, hogy mely országban vonták el a szállítmányt a vámellenőrzés alól. Ez a keresési eljárás azonban igen nehézkes volt, hiszen a jogszabály szerint csak az árutovábbítás megindításától (a szállítmány feladásától) számított 10 hét elteltével kellett elkezdeni az áru felkutatását. Ez számos esetben nem vezetett eredményre. A procedúra összesen 12 hónapig tarthatott, és ha az indító vámhivatal ez idő alatt nem értesítette a kezest a tartozás tényéröl, akkor a vámtartozás behajthatatlanná vált.

A korábban felvázolt számítógépesítési folyamat első lépése az árutovábbítás vámeljárás elektronizálása volt. Az árutovábbítási eljárás lényege tehát, hogy ha egy olyan árut szállítanak az Európai Unió vámterületén egy pontról egy másikra, amelyet valamilyen oknál fogva vámfelügyelet alatt kell tartani, akkor az áru az egyik (az indító) vámhivatal felügyelete alól a másik (a rendeltetési) vámhivatal felügyelete alá úgy kerül, hogy árutovábbítási eljárás alá vonják. Az új típusú eljárás alkalmazása során a példánkban említett fuvarozónak elektronikus üzenetben, a vámhatóság által üzemeltetett külső kommunikációs központon (KKK-n) keresztül kell benyújtania árunyilatkozatát az indító vámhivatalnál, a vámhivatal pedig a nyilvántartásba vételt követően saját informatikai rendszeréböl egy úgynevezett

\footnotetext{
${ }^{515}$ A Bizottság (EU) 2016/578 végrehajtási határozata (2016. április 11.) az Uniós Vámkódexben előírt elektronikus rendszerek kifejlesztésére és telepítésére vonatkozó munkaprogram létrehozásáról

${ }^{516}$ New Computerised Transit System
} 
továbbítási kísérő okmányt nyomtat ki, ami kíséri a szállítmányt a rendeltetési hivatalig. A fő különbség a régi és az új rendszer között azonban az, hogy az indulási vámhivatal már a szállítóeszköz indulásakor elektronikus üzenetben értesíti mind a rendeltetési, mind pedig az esetleges átléptető vámhivatalt az elindított szállítmányról. Amikor a továbbított áru megérkezik a rendeltetési vámhivatalhoz (példánkban Kölnbe), erről a kölni vámhivatal perceken belül küld egy elektronikus üzenetet Záhonyba. Ha ez az üzenet az indító vámhivatal által meghatározott bemutatási határidőt (ez általában hét nap) követő napon nem érkezik meg, az indító vámhivatal azonnal elindítja a keresési eljárást (tehát nem 10 hét, hanem nyolc nap múlva!). Az eljárás azonban itt még nem ér véget. A rendeltetési vámhivatalnak ugyanis el kell döntenie, hogy milyen áruvizsgálatot tart, majd az elvégzett áruvizsgálatról ismét elektronikus üzenetet küld az indító hivatalnak. Ez az üzenet az indító vámhivatal számára azt jelenti, hogy az eljárás rendben befejeződött, és az árutovábbítási eljáráshoz nyújtott vámbiztosíték felszabadítható. Ennek az üzenetnek a megérkezési értesítést követő hat napon belül kell megérkeznie az indító vámhivatalhoz, ellenkező esetben az indító vámhivatalnak azonnal keresési eljárást kell kezdeményeznie. ${ }^{517}$

Magyarország 1996-tól 2004-ig tagja volt az Egységes Árutovábbítási Eljárásról szóló Egyezménynek (a továbbiakban: tranzitegyezmény), amely gyakorlatilag a közösségi árutovábbítási eljárás szabályainak átvétele volt az EFTA- és a CEFTAországok által. ${ }^{518}$ Már e jogszabály 2000 . évi módosítása (és természetesen a közösségi vámkódex egyidejü módosítása is) lehetővé tette az árutovábbítási eljárás elektronizálását. Az NCTS (New Computerised Transit System - Új Számítógépesített Árutovábbítási Rendszer) azonban csak 2003. október 1-jén, az evám stratégia első pilléreként indult, és bevezetése folyamatosan történt. A rendszer bevezetése és müködtetése által Magyarország eleget tett annak az európai uniós követelményrendszernek is, amelyet a Tanács mellett müködő Vámunió Munkacsoport által gondozott többéves stratégiai tervben (Multiannual Strategic Plan) fogalmaztak meg: „Az interoperabilitást szükséges létrehozni a közösségi és nemzeti váminformatika területén belül, amelynek keretében a tagállamok és a Közösség vámrendszerei cserélnek egymással információt, de nem csak a váminformatikai, hanem más informatikai rendszerek között is." ${ }^{519}$ A rendszer bevezetését alapos tervezőmunka előzte meg, melynek során a többéves stratégiai tervben említett információcsere feltételeinek megteremtése érdekében a Vám- és Pénzügyőrségnél elindított interoperabilitási program munkatársai több lehetséges megoldást is fontolóra vettek. Végül a program keretében müködő NCTS_HU alprojekt a következő megállapításra jutott: „A jelenleg használt nemzeti vámregisztrációs rendszer (VÁMREG) nem alkalmas az NCTS által elöirt üzenetcserékre, igy két fö irány áll rendelkezésre ahhoz, hogy a feltételeket teljesiteni tudjuk:

- az új magyarországi nemzeti tranzitalkalmazás (NTA) kifejlesztése, ez az irány még kétfelé bontható (NTA $+E C N$ vagy ún. tiszta NTA), vagy

- az EU által kifejezetten az NCTS-re kifejlesztett MCC+ECN (Minimal Common Core-MCC) rendszer alkalmazása. "520

\footnotetext{
517 Sz.n.Tájékoztató az új számítógépesitett tranzit rendszer magyarországi bevezetéséröl. Bp.,VIVA Média Holding, 2003., pp. 9-11.

${ }^{518}$ Lásd: 83/1996. (VI. 14.) Korm. rendelet az Egységes Árutovábbítási Eljárásról szóló Egyezmény kihirdetéséről

${ }^{519}$ VARGA János (szerk.): A rendészeti szervek nemzetközi együttmüködése, p. 65.

${ }^{520}$ TAKÁTS Beáta - KovÁCs László: A számítógépesitett tranziteljárás bevezetése Magyarországon, az NCTS-projekt elinditása és előrehaladása. Pénzügyőr Melléklet, 2002/12. pp. 1-10.
} 
A tranzitegyezmény elöírásainak megfelelően 2003. október 1-jén Magyarországon is bevezették az NCTS-t. A rendszer a 3.1 fázissal indult, amelynek keretében normál eljárásban megvalósult a vámhivatalok közötti elektronikus üzenetcsere, a papír alapon benyújtott vámáru-nyilatkozat ${ }^{521}$ megtartásával, és csatlakoztak a rendszerhez az engedélyezett feladók ${ }^{522}$ és az engedélyezett címzettek ${ }^{523}$.

Néhány hónapon belül újabb jelentős mérföldkőhöz érkezett a rendszer üzemeltetése: 2004. május 1-jén Magyarország csatlakozott az Európai Unióhoz, ezzel a vámunióhoz is. $\mathrm{Az}$ elektronikus árutovábbítás szempontjából ez nem okozott semmilyen nehézséget, hiszen míg Magyarország eddig az időpontig a tranzitegyezmény egyik szerződő államaként, addig május 1-jétől már az Európai Unió teljes jogú tagországaként vett részt az NCTS üzemeltetésében. 2004. május elsején az NCTS országos help desk szolgálatához pusztán olyan vámjogi, vámeljárási kérdésekkel fordultak a vámhatóság munkatársai, amelyek a vámkódex rendelkezéseinek alkalmazására irányultak. Technikai, informatikai jellegű probléma nem adódott, ügyféli megkeresés pedig egyáltalán nem volt. ${ }^{524}$ Ezzel ellentétben a Vámés Pénzügyőrség Országos Parancsnokságán (VPOP) 2002 elején létrejött Interoperabilitási Projekt (IOP) másik alprojektje, az ITMS_HU (integrált tarifakezelö rendszer - Integrated Tariff Management System, ITMS) megjelölésű csoport, amely a további szükséges fejlesztéseket, elsősorban a vámárunyilatkozat-feldolgozó rendszer fejlesztését végezte, jóval eseménydúsabb napokat élt át. Röviden összefoglalva: a május elsején indult vámárunyilatkozat-feldolgozó rendszer (Customs Declaration Processing System, CDPS) múködésében nem várt leállások voltak, amelyre idővel a sajtó, ennek következtében pedig a kormányzat is felfigyelt. ${ }^{525}$ A két alprojekt (az ITMS_HU és az NCTS_HU) müködését illetően több tanulság szürhető le. Egyrészt jelentőss kockázat rejlik abban, ha több nagymértékü változást egyszerre kívánunk bevezetni. Az NCTS esetében a 2004-es EU-csatlakozáskor már nem okozott problémát a rendszer kezelése sem a pénzügyőrök, sem pedig az ügyféli kör számára, míg a CDPS rendszer müködése az új jogszabályi környezet bevezetésével együtt indult. A másik megállapítás a kommunikációra vonatkozik: egyetlen szervezet sem nélkülözheti a kríziskommunikációs terv kidolgozását. Ennek birtokában a CDPS esetében is megelőzhetö lett volna a kialakult helyzet: „, a vámhatóságról olyan kép alakulhatott ki, hogy egymaga nem képes megoldani válsághelyzeteket, a kormányfo" "feddése" szükséges ahhoz, hogy intézkedjen a megoldás érdekében. Pedig a fejlesztések, a

\footnotetext{
${ }^{521}$ Az egységes vámáru-nyilatkozat 1. példánya.

${ }^{522}$ Engedélyezett feladó: olyan gazdálkodó, amely a vámhatóság előzetes engedélyével vámhivatali közremüködés nélkül indíthat árukat az uniós árutovábbításban. Ehhez saját összkezességi engedélye alapján köt le biztosítékot, saját maga nyomtatja ki az árut kísérő okmányt, azt saját engedélyezett bélyegzőjével hitelesíti, és saját vámzárat alkalmaz. A jogintézmény előnye, hogy az engedélyes a vámhivatal nyitvatartási idején kívül is indíthat árutovábbítást.

${ }^{523}$ Engedélyezett címzett: olyan gazdálkodó, amely a vámhatóság előzetes engedélyével vámhivatali közremüködés nélkül érkeztethet árukat az uniós árutovábbításban. A jogintézmény előnye, hogy az engedélyes a vámhivatal nyitvatartási idején kívül is érkeztethet árukat, azokat kirakhatja, felszabadítva így a szállítóeszközt.

${ }^{524}$ Jelen tanulmány szerzője a projekt teljes ideje alatt az NCTS_HU alprojekt tagja, később az NCTS Help desk szolgálat vezetője volt - ráadásul 2004. május elsején ügyeleti szolgálatot látott el. A projekt tevékenységének felvázolása ily módon jórészt saját tapasztalatokra épül.

${ }^{525}$ Részletesen lásd: SuBA László: A vámhatóság interoperabilitása - és annak kommunikációja (A 2004 es EU-csatlakozás kihívásai). In: Hadtudományi Szemle 2015/4. pp. 306-315.
} 
munkaerö-átcsoportositások folyamatban voltak, és - lássuk be - a kormányzati elvárások is kommunikálhatók lettek volna egy vezetői értekezlet keretében ". 526

\subsection{Az NCTS fejlesztésének lépései}

Az új számítógépesített árutovábbítási rendszer technikai hátterét a tagállamok többsége által alkalmazott MCC rendszer adta. Csak nagyon kevés ország döntött amellett, hogy saját fejlesztésű rendszert használjon. Természetesen e szoftverek is ugyanazt ,tudták”, mint az MCC, de a tapasztalatok azt mutatták, hogy a rendszerhibák észlelése, jelzése a fejlesztő felé, illetve kijavítása sokkal hatékonyabban müködik, ha több ország felhasználói egységesen lépnek fel a hibák javítása érdekében.

Az NCTS müködése még hatékonyabbá vált az elektronikus garanciakezelés 2005. június 1-jei indulásával. A garanciakezelő rendszer (Guarantee Management System, GMS) a garanciák elektronikus nyilvántartásával és a biztosíték-lekötés és felszabadítás gyors, jól nyomon követhető módjával támogatja az árutovábbítás lebonyolítását. A rendszer legfontosabb előnye, hogy lehetetlenné teszi a referenciaösszeg (gyakorlatilag a biztosított vagy biztosítottnak tekintett garanciakeret) túllépését. Korábban előfordult olyan eset, hogy összkezességi engedéllyel rendelkező gazdálkodó átmenetileg akkora összeget kötött le az árutovábbítási eljárásban úton lévő szállítmányai biztosítékaként, amely összeg jelentősen meghaladta a rendelkezésre álló keretösszeget. Ez egészen egyszerüen oly módon volt lehetséges, hogy az összkezesség keretében az egyes árutovábbítási eljárás alatt lévő szállítmányokhoz lekötött és felszabadított összegeket az engedélyesek papír alapon, egy, a vámhatóság által elözetesen hitelesített nyilvántartásban (könyvben) tartották nyilván. Ennek az volt a kockázata, hogy ha az úton lévő szállítmányokat elvonják a vámfelügyelet alól, és emiatt vámtartozás keletkezik, annak csak egy részére állt rendelkezésre lekötött biztosíték.

Miután az elektronikus árutovábbítás normál lefolyása informatikailag szinte teljesen támogatott volt, gondolni lehetett arra is, hogy a le nem zárult eljárások kezelését is számítógépesítsék. 2005. december 1-jétől tehát az árutovábbítási eljárás alatt lévő szállítmányok keresési eljárásais elektronikusan, vagyis jól dokumentáltan és gyorsan történik.

Az NCTS keretében indított árutovábbításokat kezdetben papír alapon lehetett indítványozni. 2004 februárjától azonban lehetőség nyílott arra, hogy a vámárunyilatkozatot az ügyfelek elektronikus üzenet (IE015 üzenet) formájában nyújtsák be; e lehetőség az EU-csatlakozás időpontjától kezdve az engedélyezett feladók számára kötelezettséggé vált. Az árutovábbítási vámáru-nyilatkozat elektronikus úton való benyújtása 2005. július 1-jétől vált kötelezővé, de az erről szóló tanácsi rendelet ${ }^{527}$ nyújtotta lehetőséget kihasználva, a magyar vámhatóság 2006 végéig még elfogadta a papír alapú árunyilatkozatokat. Ezt követően azonban már csak IE015 üzenet formájában lehet az MCC-ben árutovábbítást kezdeményezni - a turistaforgalmat és az üzemszünetet kivéve. ${ }^{528}$

\footnotetext{
${ }^{526}$ SUBA: i. m. p. 315.

${ }^{527}$ A Tanács 837/2005/EK rendelete (2005. május 23.) a Közösségi Vámkódex létrehozásáról szóló 2913/92/EGK tanácsi rendelet végrehajtására vonatkozó rendelkezések megállapításáról szóló 2454/93/EGK bizottsági rendelet módosításáról

${ }^{528}$ TELEKI József: Búcsú a T-árutovábbitástól. Vám-Zoll, 2005. július, p. 15.
} 
Már az NCTS bevezetését megelőző időszakban több gazdálkodói fórumon felvetődött az az ügyféli igény, hogy az engedélyezett címzettek megérkeztethessék a részükre TIR eljárásban továbbított árukat. Ettől a VPOP akkoriban határozottan elzárkózott, mert a TIR-egyezmény nemzetközi (vagyis az EU keretein túlmutató) megállapodás, amely nem engedi meg azt, hogy a vámhatóságon kívül más személy igazoljon valamely joghatást kiváltó eseményt, például a továbbított áru megérkezését a rendeltetési helyre. Néhány évvel később azonban ,az Európai Bizottság elhatározta, hogy az NCTS-t a közösségen belüli TIR-eljárásokra is kiterjeszti. A rendszer teljes bevezetése elött [...] 10 ország részvételével kísérleti projekt létrehozására került sor. A projekt munkájában Magyarország az elsö pillanattól részt vesz, hiszen a Közösségbe irányuló TIR-eljárások jelentös része magyar külső határokról indul" ${ }^{529}$ A pilot projekt keretében 2005 augusztusától hat magyarországi vámhivatal indította el a nála kezdeményezett árutovábbítások szállítmányait a TIR-igazolvány mellett az MCC-ben is. A kísérlet sikeresnek bizonyult. „, Mivel a projektben részt vevö valamennyi tagállam vállalta, hogy amennyiben NCTS-ben indított TIR-szállitmány érkezik hozzájuk, úgy a megérkezés tényéröl elektronikus üzenetben értesiti az indító hivatalt, igy a projektben részt vevö hivataloknál a szokásos többhetes elintézési idö helyett 2-3 napra csökkent az átlagos visszaértesitési idötartam. " ${ }^{530}$ Az NCTS-TIR projekt indításához szorosan kapcsolódik az a jogszabályváltozás, amely lehetővé tette, hogy az engedélyezett címzettek TIR-eljárásban továbbított szállítmányokat is érkeztethessenek. ${ }^{531} \mathrm{~A}$ rendelkezést a bizottsági rendelet preambulumának első bekezdése így indokolja: „ $A$ Közösség számára fontos a nemzetközi kereskedelem, ezért szükséges a TIR-eljárásra vonatkozó vámalakiságok modernizálása. [...] A gazdasági szereplök igényeinek kielégitése és a nemzetközi kereskedelem elösegitése érdekében kivánatos olyan rendelkezések kidolgozása a meglévö közösségi/egységes árutovábbitási szabályok alapján, amelyek lehetövé teszik az engedélyezett címzetti státusz alkalmazását a TIReljárással kapcsolatban." 532 E rendelkezések gyakorlati előnye a gazdálkodók számára az, hogy az engedélyes pénzügyőr jelenléte nélkül leveheti a vámzárat, lepakolhatja a szállítmányt a szállítóeszközről, és így nem kell álláspénzt fizetnie. ${ }^{533}$ Az NCTS-TIR pilot projekt Magyarországon 2006. november 1-jén kezdödött, uniós szinten pedig 2009. január 1-jétől kötelező a TIR-igazolvánnyal indított árutovábbítások MCC-be való rögzítése és az ilyen áruk MCC-ben való érkeztetése. Természetesen mindez csak az Európai Unió területén szállított árukra vonatkozik, tehát ha egy szállítmány kilép az EU-ból, a kiléptető vámhivatalnak az MCC-ben érkeztetnie kell a TIR-t.

Az NCTS-ben továbbított áruk keresése az említett fejlesztések mellett továbbra is kiemelt figyelmet kapott, hiszen az elektronikus árutovábbítás bevezetése óta 2007 év végéig több mint 30 millió nemzetközi árutovábbítás indult a rendszerben. Az árutovábbítások elintézési határideje a korábbi 2-4 hónapról az esetek több mint felénél három napra, 90 százaléka esetében nyolc napra esett vissza. Ugyanakkor a nyitott tételek száma továbbra is magas volt, mintegy $5 \%$ körül mozgott, ezért szükségessé vált

\footnotetext{
${ }^{529}$ TELEKI József: NCTS/TIR projekt Magyarországon. Vám-Zoll, 2005. október, pp. 3-4.

530 Uo.

531 A Bizottság 883/2005/EK rendelete (2005. június 10.) a Közösségi Vámkódex létrehozásáról szóló 2913/92/EGK tanácsi rendelet végrehajtására vonatkozó rendelkezések megállapításáról szóló 2454/93/EGK rendelet módosításáról

532TELEKI: i. m.

${ }^{533}$ TORDA Csaba: Engedélyezett címzett a TIR Egyezményben. Vám-Zoll, 2005. október, pp. 5-6.
} 
az elintézetlen tételek kezelésére vonatkozó eljárás felülvizsgálata. ${ }^{534} 2009$. július 1jétől ezért új keresési és kiszabási eljárást vezettek be.

Ugyanettől a naptól kezdve került sor a számítógépesített tranzit rendszerben a biztonsági és védelmi típusú adatok kezelésének bevezetésére. Az egész vámigazgatási tevékenységet átfogó reform szomorú kezdete 2001. szeptember 11-e volt, amikor az Egyesült Államokban terroristák összehangolt támadásokat követtek el, és a többi között a földdel tették egyenlővé a Világkereskedelmi Központ (World Trade Center) ikertornyait. Ennek és számos ezt követő terrorcselekménynek a hatására a Vám Világszervezet (World Customs Organisation, WTO) megalkotott egy keretrendszert, amely megteremtette a vámigazgatás kockázatkezelési tevékenységének a keretfeltételeit. Az Európai Unió, csatlakozva ehhez a kezdeményezéshez, megalkotta az uniós vámjog úgynevezett biztonsági módosításait, ${ }^{535}$ amelyek 2007 . január elsején léptek hatályba. A módosító jogszabályok által újonnan bevezetett jogintézmények közé tartozik például az engedélyezett gazdálkodó (Authorised Economic Operator, AEO) és a belépési, illetve a kilépési gyüjtő árunyilatkozat is. A biztonsági és védelmi kockázatelemzést két lépcsőben vezették be. Az első fázis során a behozatali ellenőrző rendszerben (Import Control System, ICS) bejelentett import irányú szállítmányok, a második fázisban pedig az NCTS-ben bejelentett import és kiviteli irányú, illetve a kiviteli ellenőrző rendszerben (Export Control System, ECS) bejelentett szállítmányok kockázatelemzése valósult meg. ${ }^{536}$

Az NCTS folyamatosan teret nyer az EU-n kívül is. Az elmúlt években kísérleti jelleggel sor került a SPEED (Single Portal for Entry or Exit of Data - Egyetlen Portál a Belépési és Kilépési Adatoknak) projekt elindítására is. A kísérleti projekthez csatlakozott országok (így Magyarország is) azt vállalták, hogy a TIR-egyezmény szerinti árutovábbítások adatait az orosz határon történő beléptetés meggyorsítása érdekében elektronikus úton előreküldik az orosz vámhatóságnak. ${ }^{537}$

\subsection{Az elektronikus árutovábbítás jövöje}

Az Európai Unió hatályos vámügyi cselekvési programja szerint a program céljainak kitüzésekor figyelembe kell venni az elkövetkező évtized vámügyi vonatkozású problémáit és kihívásait. A program középpontjában - összhangban a vámhatóságok küldetésével - az Unió pénzügyi és gazdasági érdekeinek a védelme, valamint a biztonság és a védelem fenntartása kell, hogy álljon. Továbbra is hangsúlyos cél a kereskedelem megkönnyítése, a többi között a csalás elleni küzdelemre irányuló együttes erőfeszítések megtétele, valamint a vámhatóságok adminisztratív kapacitásainak növelése révén. Az informatikai rendszereknek létfontosságú szerepük van, és lehetővé kell tenni, hogy a program az uniós jog alapján létrehozott új vám vonatkozású informatikai rendszereket tartalmazzon. A vámigazgatás rugalmasságának és hatékonyságának növelése érdekében az európai informatikai rendszereknek szükség esetén közös fejlesztési modelleken és IT-architektúrán kell alapulniuk. A programban kellő fontosságot kell tulajdonítani a meglevő európai váminformatikai rendszerek

\footnotetext{
${ }^{534}$ KoCsIS Gábor: Új keresési és kiszabási eljárás az NCTS-ben. Vám-Zoll, 2008/1. pp. 9-10.

${ }^{535}$ Az Európai Parlament és a Tanács 648/2005/EK rendelete (2005. április 13.) a Közösségi Vámkódex létrehozásáról szóló 2913/92/EGK tanácsi rendelet módosításáról; a Bizottság 1875/2006/EK rendelete (2006. december 18.) a Közösségi Vámkódex létrehozásáról szóló 2913/92/EGK tanácsi rendelet végrehajtására vonatkozó rendelkezések megállapításáról szóló 2454/93/EGK rendelet módosításáról

${ }^{536}$ FERENCSIK Tamás: A biztonsági és védelmi kockázatelemzés közös kockázati kritériumai automatikus végrehajtásának bevezetése a beléptetési eljárások során. Pénzügyör Melléklet, 2012/9. pp. 1-5.

${ }^{537}$ KoCSIS Gábor: NCTS - utcahossznyi előny. Pénzügyőr Melléklet, 2008/12. pp. 1-12.
} 
működésének és az uniós vámkódex végrehajtásához szükséges új európai informatikai rendszerek kifejlesztésének. ${ }^{538}$ Ezek között témánk szempontjából különösen fontosak a vámárumozgási rendszerek, különösen az új számítógépesített árutovábbítási rendszer (NCTS), az NCTS-TIR Oroszország, a kiviteli ellenőrzési rendszer (ECS) és a behozatali ellenőrzési rendszer (ICS).

A következő alkalmazások/elemek támogatják ezeket a rendszereket: a harmadik országokkal történő adatcserét szolgáló rendszer (SPEED híd), a SPEED Edifact átváltó csomópont (SPEED-ECN), a standard SPEED tesztalkalmazás (SSTA), a standard árutovábbítási tesztalkalmazás (STTA), az árutovábbítási tesztalkalmazás (TTA), a központi szolgáltatások/referenciaadatok (CSRD2), valamint a központi szolgáltatások/irányítási informatikai rendszer (CS/MIS). ${ }^{539} \mathrm{Az}$ új számítógépesített árutovábbítási rendszer (NCTS) korszerúsítése projekt célja, hogy hozzáigazítsa a jelenlegi transzeurópai NCTS rendszert az uniós vámkódex szerinti új követelményekhez, mint amilyen a szállítás közben történt események regisztrálása, az információcserének az Uniós Vámkódex adatkövetelményeihez való igazítása, valamint a más rendszerekhez kapcsolódó interfészek korszerüsítése és kifejlesztése.

A gazdálkodóknak meg kell tenniük a szükséges lépéseket annak érdekében, hogy legkésőbb a munkaprogramban meghatározott záró dátumok vagy adott esetben a tagállamok által a nemzeti tervük keretében meghatározott záró dátumok szerinti naptól kezdve képesek legyenek használni a bevezetett rendszereket. Az NCTS-re vonatkozó záró dátum eredetileg 2020. március 2 -a volt, ${ }^{540}$ azonban, mivel a tagállamok erőfeszítései ellenére egyes rendszereket csak részlegesen lehet telepíteni eddig az időpontig, az új, jelenleg hatályos határidő 2025 . december $31 .{ }^{541}$

\section{Nemzetközi tapasztalatok, jó gyakorlatok}

\subsection{Arumozgás-felügyelet az Európai Unióban}

Az áruszállítási rendszerek Csaba Zágon szerint három fő tényező kielégítésére koncentrálnak: a költséghatékonyságra, az idő tényezőre, és a biztonságra, amelyek látszólag egymásnak ellentmondó szempontok. ${ }^{542} \mathrm{~A}$ biztonságot ezen felül a logisztikai lánc teljes hosszában, elterjedt kifejezéssel „ajtótól ajtóig” (door-to-door security) értelmezik. ${ }^{543}$ Aleksandar Erceg megvizsgálta az EU e-vám rendszereinek, köztük különösen a számítógépesített árutovábbítási rendszerének (a továbbiakban: NCTS) hatását a kereskedelemre és a rendszer horvátországi bevezetéséről szerzett

\footnotetext{
${ }^{538}$ Az Európai Parlament és a Tanács 1294/2013/EU rendelete (2013. december 11.) a 2014 és 2020 közötti időszakra szóló, európai uniós vámügyi cselekvési program (Vám 2020) létrehozásáról, valamint a 624/2007/EK határozat hatályon kívül helyezéséről

${ }^{539} \mathrm{Uo}$

${ }^{540}$ A Bizottság (EU) 2016/578 végrehajtási határozata (2016. április 11.) az Uniós Vámkódexben előírt elektronikus rendszerek kifejlesztésére és telepítésére vonatkozó munkaprogram létrehozásáról

${ }^{541}$ Az Európai Parlament és a Tanács 952/2013/EU rendelete (2013. október 9.) az Uniós Vámkódex létrehozásáról, 278. cikk (3) bek. e) pontja. Módosította: az Európai Parlament és a Tanács (EU) 2019/632 rendelete (2019. április 17.) a 952/2013/EU rendeletnek az Uniós Vámkódexben elöírt elektronikus adatfeldolgozási eljárásoktól eltérő eszközök átmeneti alkalmazásának meghosszabbítása céljából történő módosításáról.

${ }^{542}$ CSABA Zágon: Kritikus infrastruktúra - gazdasági biztonság. Hadtudomány, 2012/3-4. pp. 171-175.

${ }^{543}$ Horváth Attila, CSABA Zágon: Critical Transport Infrastructure Protection: A Reserach on the Security of the Supply Chains. Economics and Management, 2015/2. pp. 47-54.
} 
tapasztalatait. Erceg szerint a több országon át közlekedő áruk az NCTS-nek és az elektronikus vámáru-bejelentési rendszereknek köszönhetően felgyorsultak, rövidebb várakozási és áthaladási időkkel kell számolni, s ez a tény a a kereskedelem költségeit is mérsékelte. A horvát vámigazgatás rendkívül pozitívan értékelte a rendszer használatából fakadó előnyöket a 2011. július 1. és 2013. május 1. közötti időszakban végrehajtott 1,1 millió árutovábbítás tapasztalatai alapján. A szerző számítása szerint ebben az időszakban összesen 232.500 óra időmegtakarítást értek el az NCTS alkalmazásának köszönhetően. ${ }^{544}$

$\mathrm{Az}$ árumozgás-felügyelet hatékonysága és ezzel szoros összefüggésben a gazdálkodói előnyök biztosítása érdekében tette közzé Smart Border 2.0 (Okos határ 2.0) elnevezésü javaslatát 2017 novemberében Lars Karlsson, a Vám Világszervezet korábbi elnöke, a svéd vámhatóság helyettes vezetője. ${ }^{545} \mathrm{~A}$ tanulmány szerint az intelligens határok magukban foglalják a modern technológia alkalmazását, a kockázatkezelést, a nemzetközi együttmüködést, valamint a nemzetközi szabványok alkalmazását. Az intelligens határok felismerik, hogy az emberek és az áruk különböző kockázatokat hordoznak, és így elkülönítik öket különböző kockázati csoportokba. A gyakorlatban az intelligens határ integrálja az engedélyezett gazdálkodó (Authorised Economic Operator, AEO) elönyeit, az egyszerüsített elektronikus vámáru-nyilatkozat alkalmazását, valamint a szállítóeszköz vezetőjének megbízhatóként történt előzetes regisztrációját. A rendszer az egyszerűsített vámáru-nyilatkozatot automatikusan feldolgozza és a kockázatot értékeli. A komplex rendszer része a rendszámleolvasó kamerarendszer, továbbá a teherautó vezetőjének okostelefonjára letöltött alkalmazás, amellyel - megadott átlépési engedély esetén - nyitható a határsorompó. ${ }^{546}$

\subsection{Harmadik országok tranzitrendszerei}

Ajordán vámhatóság 2008 óta alkalmazza az elektronikus tranzitkövetési rendszert. A rendszer a GPS adatai alapján valós időben figyeli a teherautó mozgását. A riasztás akkor aktiválódik, ha rendellenességet észlel, például ha a szállítóeszköz letér az előzetesen kijelölt útvonalról, vagy ha a vámzárat meg akarják bontani. Ebben az esetben a mobil ellenőrzési csoport várhatóan kevesebb, mint 30 perc alatt ellenőrzés alá vonja a teherautót és a szállítmányt. ${ }^{547}$

Kelet-Afrika öt országában - Ugandában, Ruandában, Burundiban, a Kongói Demokratikus Köztársaságban és Dél-Szudánban -az árutovábbítási műveletek lebonyolítása hosszú ideig konvojrendszeren keresztül történt, papíralapú árunyilatkozatok, kísérőszemélyzet és tranzitellenőrzési pontok igénybevételével. 2013ban az ugandai vámhatóság úgy döntött, hogyaz árutovábbítás során szállított áruk valós idejü nyomon követését lehetővé tevő elektronikus árufuvarozási rendszert vezet be. A régió többi országa hamarosan hasonló rendszert állított föl, amelynek

\footnotetext{
${ }^{544}$ ERCEG, Aleksandar: The New Computerized Tranzit System and E-Customs Influence on Savings in Tranzit Time and Cost. In: SegetluJA, Zdenko et al. (eds.): Business Logistics in Modern Management, XIII. International Scientific Conference, University of Josip Juraj Strossmayer, Osijek, HR, 2013. pp. $143-152$.

${ }^{545}$ KARLSSON, Lars: Smart Border 2.0. Avoiding a hard border on the island of Ireland for Customs control and the free movement of persons. European Union, 2017. (Letöltve: 2019. március 14-én.) http://www.europarl.europa.eu/supporting-analyses

${ }^{546}$ KARLSSON: i. m. p. 25.

${ }^{547}$ YASUI, Tadashi: Transit Facilitation for Regional Economic Integration and Competitiveness. WCO Research Paper No. 28 (April 2013) (Letöltve: 2019. február 14.) http://www.wcoomd.org//media/wco/public/global/pdf/topics/research/research-paper-series/28_transit_yasui_en.pdf?la=en
} 
eredményeként minden országnak saját e-jármükövetési rendszere volt. 2014-ben az ún. északi folyosó vámszervei közül Kenya és Ruanda vámigazgatási szervei csatlakoztak az ugandai elektronikus rendszerhez, s ezt a lépést követte 2017-ben a regionális elektronikus rakománykövető rendszer (Regional Electronic Cargo Tracking System, RECTS) nevü regionális rendszer elindítása. A három vámigazgatás ezt az egységes platformot használja, amely lehetővé teszi számukra, hogy egyetlen rendszerben tartsák nyilván a területükön haladó szállítmányokat. A technikai eszközöket a három bevételi hatóság közösen vásárolta meg. ${ }^{548}$

A szingapúri kikötői vámrendszer egy része kódok leolvasásával müködik, mégpedig blockchain-módszerrel, amelynek az az elönye, hogy jól követhető minden illetéktelen módosítás. A TradeLens rendszert a dán Maersk hajóstársaság és az amerikai IBM számítástechnikai világcég dolgozta ki. ${ }^{549}$

\section{4. Összegzés}

A vámigazgatásban - egyéb szempontok mellett - mindmáig nagy jelentőséget kap a költségvetés bevételeinek biztosítása. E cél érdekében az egyik kiemelt feladat azoknak az áruknak a folyamatos figyelemmel kísérése, amelyek után a szállítás alatt ugyan jogszerüen nem fizeti meg az ügyfél a köztartozásokat, ám a vámhatósági felügyelet alól kikerült áru után vám-, illetve adótartozás keletkezik. Ezen szállítások tehát kiemelt kockázatot jelentenek.

A bemutatott példák esetében az Európai Unió, illetve az említett harmadik országok döntéshozói idejében felismerték, hogy ez a kockázat jelentősen csökkenthetö. Ennek a következő feltételei vannak:

a) már az ügyféli kérelem is elektronikusan érkezik a vámhatósághoz,

b) a szállítmány indulásáról a rendeltetési vámhivatal azonnal tudomást szerez,

c) a rendeltetési vámhivatal a vizsgálatának eredményéről azonnal tájékoztatja az indító hivatalt,

d) ha a visszaértesítés idejében nem érkezik meg, akkor az indító hivatal gyorsan képes intézkedni az áru keresése, végső soron a köztartozás beszedése iránt,

e) végül pedig az ügyfél az elektronikus üzenetek révén nyomon tudja követni az általa feladott szállítmány sorsát.

Az árumozgás ellenőrzése (ami jelentheti az adófelfüggesztés alatt álló jövedéki vagy más termék szállításának ellenőrzését éppúgy, mint a fentebb részletesen tárgyalt árutovábbítást) világszerte folyamatos technológiai fejlödésen megy keresztül. A tapasztalatok azt mutatják, hogy e fejlesztések gyakorlatba való átültetése során ügyelni kell arra, hogy jelentős kockázat rejlik több nagymértékű változás egyidőben történő bevezetésében. Fontos szempont az is, hogy a bevezetés során esetleg keletkező problémák és megoldásuk kommunikálása kríziskommunikációs terv alapján történjen. A körültekintő implementálás után jól müködő árumozgás-követő rendszerek révén a vámhatóság és a gazdálkodók számára egyaránt megtakarított költség és idő megéri a befektetést.

\footnotetext{
${ }^{548}$ BAlamagA, Geofrey: Countries in East Africa cut transit time. In: WCO News 88. (Letöltve: 2019. január 11.) https://mag.wcoomd.org/magazine/wco-news-88/countries-east-africa-cut-transit-time/ 549 Sz.n. E-határ-e? HVG, 2019. március 21., p. 33.
} 


\section{Felhasznált irodalom}

[1] ARnOLD Mihály: Ma már holnap van. A magyar gazdaság és a Vám-és Pénzügyörség. VIVA Média Holding, Budapest, 2002. p. 145.

[2] Balamaga, Geofrey: Countries in East Africa cut transit time. In: WCO News 88. (Letöltve: 2019. január 11.) https://mag.wcoomd.org/magazine/wco-news88/countries-east-africa-cut-transit-time/

[3] CsABA Zágon: Kritikus infrastruktúra - gazdasági biztonság. Hadtudomány, 2012/3-4. pp. 171-175.

[4] E-határ-e? HVG, 2019. március 21., 33.p.

[5] FAZEKAS Marianna - FICZERE Lajos (szerk.): Magyar közigazgatási jog. Általános rész. 6., átd. kiad. Bp., Osiris, 2005.

[6] FERENCSIK Tamás: A biztonsági és védelmi kockázatelemzés közös kockázati kritériumai automatikus végrehajtásának bevezetése a beléptetési eljárások során. Pénzügyőr Melléklet, 2012/9. pp. 1-5.

[7] HoRvÁth Attila, CsABA Zágon: Critical Transport Infrastructure Protection: A Reserach on the Security of the Supply Chains. Economics and Management, 2015/2. pp. 47-54.

[8] KARLSSON, Lars: Smart Border 2.0. Avoiding a hard border on the island of Ireland for Customs control and the free movement of persons. European Union, 2017. (Letöltve: 2019. március 14-én.) http://www.europarl.europa.eu/supporting-analyses

[9] Kocsis Gábor: Új keresési és kiszabási eljárás az NCTS-ben. Vám-Zoll, 2008/1. pp. 9-10.

[10] KOCSIS Gábor: NCTS - utcahossznyi előny. Pénzügyőr Melléklet, 2008/12. pp. $1-12$.

[11] SUBA László: A vámhatóság interoperabilitása - és annak kommunikációja (A 2004-es EU-csatlakozás kihívásai). In: Hadtudományi Szemle 2015/4.pp. 306315.

[12] Tájékoztató az új számítógépesitett tranzit rendszer magyarországi bevezetéséröl. Bp., VIVA Média Holding, 2003.

[13] TAKÁTS Beáta - KovÁCs László: A számitógépesitett tranziteljárás bevezetése Magyarországon, az NCTS-projekt elindítása és elörehaladása. Pénzügyőr Melléklet, 2002/12. pp. 1-10.

[14] TeleKI József: Búcsú a T-árutovábbitástól. Vám-Zoll, 2005. július, p. 15.

[15] TELEKI József: NCTS/TIR projekt Magyarországon. Vám-Zoll, 2005. október, pp. 3-4.

[16] TORDA Csaba: Engedélyezett címzett a TIR Egyezményben. Vám-Zoll, 2005. október, pp. 5-6.

[17] VARGA János (szerk.): A rendészeti szervek nemzetközi együttmüködése. Rendőrtiszti Főiskola, Bp., 2009.

[18] YASUI, Tadashi: Transit Facilitation for Regional Economic Integration and Competitiveness. WCO Research Paper No. 28 (April 2013) (Letöltve: 2019. február 14.) http://www.wcoomd.org//media/wco/public/global/pdf/topics/research/research-paperseries $/ 28$ transit_yasui_en.pdf?la=en 
Jogforrások jegyzéke

[1] A Tanács 1992. október 12-i 2913/92/EGK rendelete a Közösségi Vámkódex létrehozásáról

[2] Az Európai Parlament és a Tanács 648/2005/EK rendelete (2005. április 13.) a Közösségi Vámkódex létrehozásáról szóló 2913/92/EGK tanácsi rendelet módosításáról

[3] A Tanács 837/2005/EK rendelete (2005. május 23.) a Közösségi Vámkódex létrehozásáról szóló 2913/92/EGK tanácsi rendelet végrehajtására vonatkozó rendelkezések megállapításáról szóló 2454/93/EGK bizottsági rendelet módosításáról

[4] Az Európai Parlament és a Tanács 952/2013/EU rendelete (2013. október 9.) az Uniós Vámkódex létrehozásáról

[5] Az Európai Parlament és a Tanács 1294/2013/EU rendelete (2013. december 11.) a 2014 és 2020 közötti időszakra szóló, európai uniós vámügyi cselekvési program (Vám 2020) létrehozásáról, valamint a 624/2007/EK határozat hatályon kívül helyezéséről

[6] Az Európai Parlament és a Tanács (EU) 2019/632 rendelete (2019. április 17.) a 952/2013/EU rendeletnek az Uniós Vámkódexben elöírt elektronikus adatfeldolgozási eljárásoktól eltérő eszközök átmeneti alkalmazásának meghosszabbítása céljából történő módosításáról

[7] A Bizottság 883/2005/EK rendelete (2005. június 10.) a Közösségi Vámkódex létrehozásáról szóló 2913/92/EGK tanácsi rendelet végrehajtására vonatkozó rendelkezések megállapításáról szóló 2454/93/EGK rendelet módosításáról

[8] A Bizottság 1875/2006/EK rendelete (2006. december 18.) a Közösségi Vámkódex létrehozásáról szóló 2913/92/EGK tanácsi rendelet végrehajtására vonatkozó rendelkezések megállapításáról szóló 2454/93/EGK rendelet módosításáról

[9] A Bizottság (EU) 2016/578 végrehajtási határozata (2016. április 11.) az Uniós Vámkódexben elöírt elektronikus rendszerek kifejlesztésére és telepítésére vonatkozó munkaprogram létrehozásáról

[10] 1924. évi XIX. tc. a vámjog szabályozásáról. (Letöltve: 2019. január 8-án.) https://net.jogtar.hu/ezer-ev-torveny?docid=92400019.TV\&searchUrl=/ezer-evtorvenyei\%3Fkeyword\%3D1924

[11] 1924. évi XIX. tc. - indokolás. (Letöltve: 2019. január 8-án.) https://net.jogtar.hu/getpdf?docid=92400019.TVI\&targetdate $=\&$ printTitle $=1924$ .+\%C3\%A9vi+XIX.+t\%C3\%B6rv\%C3\%A9nycikk+indokol\%C3\%A1sa\&refere $\mathrm{r}=1000 \mathrm{ev}$

[12] 1995. évi C. törvény a vámjogról, a vámeljárásról, valamint a vámigazgatásról

[13] 83/1996. (VI. 14.) Korm. rendelet az Egységes Árutovábbítási Eljárásról szóló Egyezmény kihirdetéséről

[14] 39/1976. (XI. 10.) PM-KkM együttes rendelet a vámjog részletes szabályainak megállapításáról és a vámeljárás szabályozásáról

Lektorálta: Dézsi Zsolt Dr. PhD. képzési szakértö referens Nemzetei Adó- és Vámhivatal Képzési, Egészségügyi és Kulturális Intézet dezsi.zsolt@nav.gov.hu 